\title{
A study on the antioxidant, antimicrobial and cytotoxic activity of Thymbra spicata L. var. spicata ethanol extract
}

\section{Thymbra spicata L. var. spicata etanol ekstresinin antioksidan, antimikrobiyal ve sitotoksik etkisinin} araştırılması

\author{
Nuraniye Eruygur ${ }^{1}$, Sülleyman Çetin ${ }^{1}$, Mehmet Ataşş$^{2}$, Özge Çevilk ${ }^{3}$
}

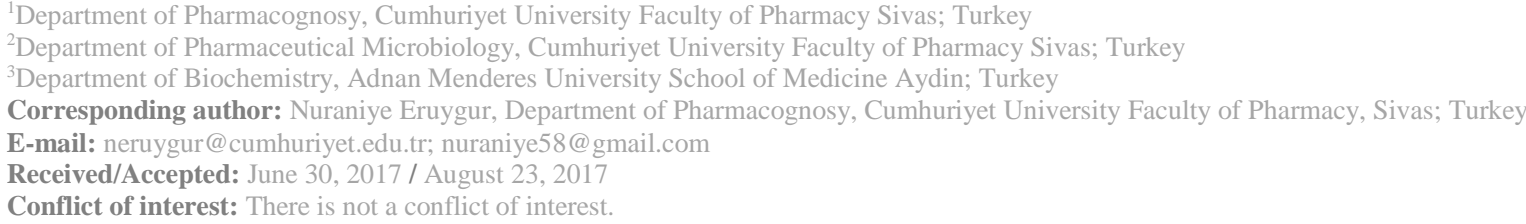

\section{SUMMARY}

Objective: Thymbra species are widely used in Turkish folk medicine as salad or herbal tea for antioxidant, antiseptic, antitussive, carminative, anti-inflammatory and antimicrobial activities. The present study was aimed to determine antioxidant, antimicrobial and cytotoxic properties of ethanol crude extract prepared from Thymbra spicata L.var. spicata. Method: The antioxidant properties of ethanol extract of Thymbra spicata L. var. spicata was investigated using 1,1diphenyl-2-picrylhydrazyl (DPPH) and 2,2-azinobis[3-ethylbenzthiazoline]-6-sulfonic acid (ABTS) radical scavenging activity, total flavonoid and total phenolic content analysis. Antimicrobial activity of the plant extract were determined using the microdilution method, while proliferative activity were evaluated by MTT assay on MCF-7 breast cancer and PC3 prostate cancer cell line.

Results: Total phenol and total flavonoid content were $216.75 \pm 0.017$ (equivalent of Gallic acid mg/g dry extract) and $78.17 \pm 0.063$ (equivalent of Quercetin $\mathrm{mg} / \mathrm{g}$ ), IC50 value for DPPH and ABTS scavenging activity was $16.91 \mu \mathrm{g} / \mathrm{mL}$ and $5.2 \pm 0.009 \mu \mathrm{g} / \mathrm{mL}$, respectively. Antimicrobial activity observed for the extract ranging between $1.25 \mathrm{and} 2.5 \mathrm{mg} / \mathrm{mL}$ as MIC value against tested microorganism. MTT assay was employed for evaluation of cytotoxic activity, ethanol extract demonstrated growth inhibitory effect against MCF-7 breast cancer cells with IC50 value $340 \mu \mathrm{g} / \mathrm{mL}$.

Conclusions: According to the obtained results, antioxidant, antimicrobial and cytotoxic activity of Thymbra spicata L.var. spicata is scientifically support the widespread use of this plant among the people.

Keywords: Thymbra spicata L.var. spicata, antioxidant, antimicrobial, cytotoxicity

\section{ÖZET}

Amaç: Tymbra türleri halk arasında antioxidant, antiseptic, antitussive, karminatif, antienflamatuvar ve antimikrobiyal özelliklerinden dolayı salata ve bitkisel çay olarak yaygın kullanılmaktadır. Çalışmamızın amacı, Thymbra spicata L. var. spicata.'dan hazırlanan ham etanol özütünün antioksidan, antimikrobiyal ve sitotoksik etkisini araştırmaktır.

Yöntem: T.spicata L.var. spicata etanol ekstresinin antioksidan aktivitesi DPPH ve ABTS serbest radikal süpürücü etki, total fenol ve total flavonoid miktar tayini yöntemleri kullanılarak değerlendirildi. Antimikrobiyal aktivitesi ise mikrodilüsyon metodu ile, sitotoksisite aktivitesi prostat kanseri PC3 hücre hattı kullanılarak MTT metoduyla değerlendirildi.

Bulgular: Total fenol ve total flavonoit miktarı kuru ekstre bazında $216.75 \pm 0.017$ (gallik asite eşdeğer mg/g) ve 78.17 \pm 0.063 (kersetine eşdeğer $\mathrm{mg} / \mathrm{g}$ ) olarak bulundu. DPPH ve ABTS radikal süpürücü etki IC50 değeri sirasılyla 16.91 $\mu \mathrm{g} / \mathrm{mL}$ and $5.2 \pm 0.009 \mu \mathrm{g} / \mathrm{mL}$ olarak bulundu. Etanol ekstresinin test edilen mikroorganizmalar karş1 minimum inhibe edici konsantrasonu 1.25-2.5 mg/mL aralığında tespit edildi. Sitotoksik aktivitenin değerlendirilmesi için MTT testi kullanıldı, etanol ekstraktı MCF-7 meme kanseri hücrelerine karşı IC50 değeri 340 g / mL olan büyümeyi önleyici bir etki gösterdi. 
Sonuç: Elde edilen bulgulara göre, Thymbra spicata L.var. spicata bitkisinin antioxidant, antimikrobiyal ve sitotoksik aktivitesi bu bitkinin halk arasındakı yaygın kullanımını bilimsel yönden desteklemektedir.

Anahtar sözcükler: Thymbra spicata L.var. spicata, antioksidan, antimikrobiyal, sitotoksisite

\section{INTRODUCTION}

Cancer is one of causes of death and being a major concern in the worldwide. Plants play very important role in drug discovery and development of cancer chemotherapeutic agents due to their multiple phytochemical compounds and great effectiveness and toxicity tolerance. In fact, most of the plant drived toxic molecules are widely used in chemotherapy. Nowadays, there is a recrudescence of interest for the natural alternative such as medicinal plants and dietary ${ }^{1}$. Reactive oxygen species (ROS), produced from extracellular and intracellular sources in excessive amounts, reacts with DNA, lipids, and cellular proteins can causes oxidative stress ${ }^{2}$ Previouse reports suggests that there is a strong relationgship between ROS and some chronic diseases such as cancer, neurologic disorder, cardiovascular disease and age related disease ${ }^{3}$. Antioxidants are the biochemical constituents produced in the body, serve as the biological defense system, in case of their inefficient, dietary antioxidants should be take in order to prevent oxidative stress from further damaging the biological system. a plethora of studies demonstrated that utilization of plant-origin antioxidants can be reduce the risk of occurrence of numerous human diseases narrated to the oxidative stress $^{4-5}$ Extensive use of antibiotics and the problem of emerging infectious dissseases which are resistance to currently available antibiotics, which made it ineveitable to search for new antimicrobials of plant origin ${ }^{6}$.

Thymbra spicata $\mathrm{L}$. is represented by four taxa and two species: T. spicata var. spicata and T. spicata var. intricata in Turkey. T. spicata is naturally found in Southeastern Anatolia, coastal areas of Thrace, Aegean and Mediterranean region of Turkey $^{7-8}$. T. spicata, is a thyme-like plant, is known as "Zahter" and "Karabas kekik" in the Southeastern Anatolia Region of Turkey due to contains a variety of aromatic compounds mainly are carvacrol and thymol. It is used in salads and tea either dry or fresh leaves and flowers. Dried aerial parts of the plant are used in the form of herbal teas, spice and to treat colic, bronchitis, asthma, coughs, diarrhoea and rheumatism in folk medicine in various regions of Turkey ${ }^{9}$. Thymbra has been reported to be used as raw material in pharmaceutical formulations due to its significant pharmacological properties in many countries ${ }^{10}$.
However, there is no available report on the pharmacological activities of extract excepet from essential oil. Therefore in the present study, the plant material was obtained from herbal market in Hatay province of Turkey and prepared ethanol extract by maceration method to study their antioxidant, antimicrobial and cytotoxic properties.

\section{MATERIAL AND METHODS}

\section{Chemicals}

1,1-Dipheny 1-2-picryl-hydrazyl (DPPH), 2,2azino-bis (3-ethylbenz- thiazoline-6-sulfonic acid (ABTS), 3-(4,5-dimethylthiazol-2-yl)-2,5diphenyltetrazolium bromide (MTT), quercetin, and gallic acid were obtained from Sigma Aldrich Co., St. Louis, USA. All other chemicals used were of analytical grade.

\section{Plant Materials}

The plant material were obtained from herbal market of Hatay province.and identificated by botanist Dr. Mehmet Tekin, Cumhuriyet University, Faculty of Pharmacy, Department of Pharmaceutical Botany.

\section{Preparation of the extract}

The dried herbs of $T$. spicata L.var. spicata were pulverized using a grinder and $100 \mathrm{~g}$ of them was macerated in $1000 \mathrm{~mL}$ of $80 \%$ ethanol (Ethanol : water $=80: 20$ ) for $48 \mathrm{~h}$ with intermittent shaking at room temperature. The crude aqueous ethanol extract was filtered through Whatman filter paper No.1. and concentrated with rotary evaporator (Buchi R-100 equipped with Vacuum Pump V-300 and Control unit I-300) at $40^{\circ} \mathrm{C}$ to constant dryness, and stored at $-20^{\circ} \mathrm{C}$ for further use.

\section{Antioxidant Activities}

\section{DPPH free radical scavenging activity}

The scavenging effect of the stable 1, 1-diphenyl2-picrylhydrazyl (DPPH)-free radical was evaluated by the method of Blois ${ }^{11}$. Sample solutions were prepared as a series of concentrations $(1,10,50,100,250,500$, and 1000 $\mu \mathrm{g} / \mathrm{mL}$ ) by diluting $2 \mathrm{mg} / \mathrm{ml}$ of extract stok solution dissolved in \%10 DMSO of methanol). Ascorbic acid was used as standard in $1-100 \mu \mathrm{g} / \mathrm{mL}$ solution. $0.1 \mathrm{mM}$ of DPPH was prepared in methanol and mixed with sample solution in a 1:3 volume to volume ratio in test tubes separately in triplicates. 
These solution mixtures shanked vigorously, then were allowed to stand at dark for $30 \mathrm{~min}$ and optical density of reduced DPPH. was measured at 517 $\mathrm{nm}$. Methanol with DPPH solution was used as blank. Scavenging DPPH. activity of plant extracts by $50 \%$ ( $\mathrm{IC}_{50}$ value) was obtained by linear regression analysis of dose-response curve plotting between $\%$ inhibition and concentrations. The $\%$ inhibition was calculated by the formula given below:

Percent $(\%)$ inhibition of DPPH activity = (Absorbans of Blank-Absorbans of Test) / Absorbans of Blank $\times 100$

\section{ABTS radical cation decolorization assay}

The scavenging activity of ABTS free radical was determined according to the method described by Re et $\mathrm{al}^{12}$.ABTS radical cations $\left(\mathrm{ABTS}^{\circ+}\right.$ ) was generated by reacting $2.45 \mathrm{mM}$ potassium persulphate with a $7 \mathrm{mM}$ aqueous ABTS stok solutions. The ABTS cation working solution was obtained by mixing the two stok solutions in equal volumes and incubate them to react for $16 \mathrm{~h}$ at $25^{\circ} \mathrm{C}$ in the dark. Before using, this solution was dilute with methanol to give the absorbance of $0.70 \pm 0.02$ at $734 \mathrm{~nm}$ and equilibrated at $30^{\circ} \mathrm{C}$. Ascorbic acid used as references standard. $1 \mathrm{~mL}$ of sample was reacted with $1 \mathrm{~mL}$ of fresh $\mathrm{ABTS}^{\cdot+}$ radical cation solution in test tubes, and absorbance is read (at $734 \mathrm{~nm}$ ) after $7 \mathrm{~min}$ incubation in the dark. ABTS radical scavenging capacity was expressed as Trolox equivalents (in $\mu \mathrm{M}$ ). per gram of dry extract.

\section{Determination of total phenolics contents}

The determination of total phenolic content was performed through Folin-Ciocalteu method with slight modifications ${ }^{13}$. Briefly, $50 \mu \mathrm{L}$ of $1 \mathrm{mg} / \mathrm{mL}$ crude extract was mixed with $450 \mu \mathrm{L}$ of distilled water and $2.5 \mathrm{~mL}$ of $1 \mathrm{~N}$ Folin-Ciocalteu reagent. After $5 \mathrm{~min}, 2 \mathrm{~mL}$ of $\% 7.5$ sodium carbonate was added. The absorbance of the solution was read at $730 \mathrm{~nm}$ in spectrophotometer after $30 \mathrm{~min}$ of incubation at $37^{\circ} \mathrm{C}$. The total phenolics content was expressed as milligrams gallic acid (GAE) equivalents per gram of dried extract.

\section{Determination of total flavonoids contents}

The determination of flavonoids was performed according to the method developed by Misbah et $\mathrm{al}^{14}$. $500 \mu \mathrm{L}$ of crude aqueous ethanol extract prepared with methanol as $1 \mathrm{mg} / \mathrm{mL}$ were mixed with $1.5 \mathrm{~mL}$ of $\% 95$ ethanol, $0.1 \mathrm{~mL}$ of $10 \%$ aluminum chloride, $0.1 \mathrm{~mL}$ of $1 \mathrm{M}$ sodium acetate and $2.8 \mathrm{~mL}$ of deionized water. After incubation at room temperature for $30 \mathrm{~min}$, the absorbance of reaction mixture was determined by spectrophotometer at $415 \mathrm{~nm}$. Ethanol was used as a blank. The content of flavonoids was established as quercetin $\mathrm{mg} / \mathrm{g}$ dry extract. The experiments were conducted in triplicate.

\section{Antimicrobial Activities}

Aqueous ethanol extract of T.spicata L.var. spicata was determined for antimicrobial potential by micro-well dilution assay as previously reported ${ }^{15}$ against bacterial and fungal strains: Gram positive (Staphylococcus aureus (ATCC 29213) and Enterococcus faecalis (ATCC 29212)), Gramnegative (Pseudomonas aeruginosa (ATCC 27853) and Escherichia coli (ATCC 25922)) and fungal strain (Candida albicans (ATCC 10231)). Plant extracts were dissolved in $8 \%$ DMSO to prepared $20 \mathrm{mg} / \mathrm{mL}$ of stok solution. $50 \mu \mathrm{L}$ sterile distilled water was added in each well of 96-well microtiter plate. $50 \mu \mathrm{L}$ of plant extract was added into the first well and a serial two-fold dilution was performed by transferring $50 \mu \mathrm{L}$ of the suspension to the subsequent wells up till the 9th well; the final $50 \mu \mathrm{L}$ of the suspension was discarded. 10th well was added Gentamicin for bacteria and Flucanazole for Candida used as drug positive control while 11 th well was added $50 \mu \mathrm{L} 2 \%$ DMSO used as negative control and 12th well was added $50 \mu \mathrm{L}$ Mueller Hinton Broth (sterility control). Concentration of plant extract in wells ranged from 5.00 to $0.02 \mu \mathrm{g} / \mathrm{mL}$. Final inoculum size was $5 \times 10^{5} \mathrm{CFU} / \mathrm{mL}$ at bacteria and $0.5-2.5$ $\mathrm{x} 10^{3} \mathrm{CFU} / \mathrm{mL}$ at Candida in each well. Mueller Hinton Broth and Saboraud Dekstroz Broth was used for dilution bacteria and Candida culture's, respectively. Microtiter plates were incubated at 37 ${ }^{\circ} \mathrm{C}$ for bacteria and $35^{\circ} \mathrm{C}$ for Candida between 1624 hours. Afterwards, $50 \mu \mathrm{L}$ of freshly prepared 2 $\mathrm{mg} / \mathrm{mL}$ 2,3,5-Triphenyltetrazolium chloride (TTC) (Meck, Germany) was added to each well of the plate to indicate microbial growth. It was incubated at $37^{\circ} \mathrm{C}$ for a further $2 \mathrm{~h}$. Reduction in density of formazan's red color after incubation was accepted MIC value. The experiment was performed in duplicate and the standard deviation was zero.

\section{Cytotoxicity assay}

The In vitro antiproliferative activity was carried out by the colorimetric MTT assay ${ }^{16}$. Exponential growing breast cancer MCF-7 cells and prostate cancer PC-3 cells and control cells L929 mouse fibroblast cell line were plated in 96-well micropates at a density of $5 \times 10^{3}$ cells per well in $100 \mu \mathrm{L}$ of $10 \%$ FBS contained RPMI-1640 culture medium and were allowed to adhere for $16 \mathrm{~h}$, cultured at $37{ }^{\circ} \mathrm{C}$ in a humidified atmosphere of $5 \% \quad \mathrm{CO}_{2}$ before treatment. Increasing concentrations of extract $(1-1000 \mu \mathrm{g} / \mathrm{mL})$ in their 
respective extraction solvent were then added. The final concentration of ethanol in the culture medium was maintained at $0.5 \%(\mathrm{v} / \mathrm{v})$. The cells were incubated for $24 \mathrm{~h}$ in the presence or absence of extract. After incubation, $100 \mu \mathrm{L}$ of MTT solution [5 $\mathrm{mg} / \mathrm{ml}$ in PBS: medium (1:3)] was added per well, and the plate incubated for $4 \mathrm{~h}$ to allow reaction of MTT by cellular mitochondrial dehydrogenases. The excess MTT was aspirated and the formazan crystals formed were dissolved with $100 \mathrm{~mL}$ of dimethyl sulfoxide (DMSO). The absorbance of purple formazan, proportional to the number of viable cells, was measured at $595 \mathrm{~nm}$ using a microplate reader (Epoch, USA). The experiments were carried out in triplicate. The cytotoxicity of extract was presented as $\mathrm{IC}_{50}$ value, defined as the concentration that caused a $50 \%$ of cell death. The $\mathrm{IC}_{50}$ value was calculated from extract concentration - cell growth inhibition curve by Graphpad prism 7.0 software.

\section{RESULTS AND DISCUSSION}

The yields of crude ethanol extract was $16.97 \%$ calculated according to dry weight basis. Scavenging activity for free radicals of DPPH and ABTS have been widely used to evaluate the antioxidant activity of natural products from plant and microbial sources. Free radical scavenging activity of ethanolic extract $T$. spicata was quantitatively determined using DPPH assay. Figure 1 shows the results of DPPH radical scavenging assay. When the DPPH radical scavenging activity of the T.spicata extract examined, it was found that the extract have potent radical scavenging activity as quercetin in Fenton reagent environment ${ }^{17}$. Previous study on the antioxidant activities of other species of the genus Thymus measured by DPPH, showed an $\mathrm{IC}_{50}$ value of $16.15 \mu \mathrm{g} / \mathrm{mL}$ for methanol extract of T.spathulifolius ${ }^{18}, 38.2$ and $44.5 \mu \mathrm{g} / \mathrm{mL}$ for methanol and hexane fractions of T.capitatus ${ }^{19}$.

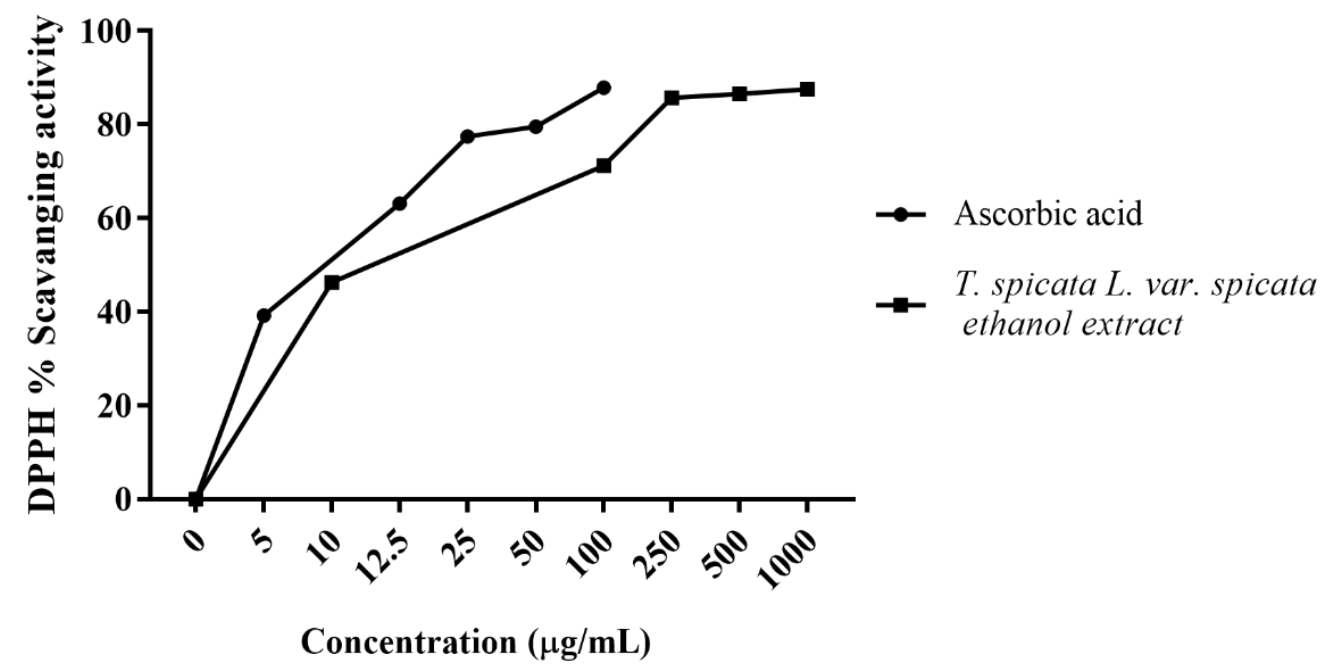

Figure 1. DPPH free radical scavenging activity of ethanol extracts of T.spicata L.var. spicata

The ABTS radical scavenging activity of the extract was given in Figure 2. When compared to $\mathrm{DPPH}$, the extract have potential ABTS radical scavenging activity in lower concentration. Therefore, the extract may be contain polar constituent which are more potent in radical scavenging activity on ABTS than DPPH, because the ABTS is water soluble radical while DPPH is water in-soluble radical. 


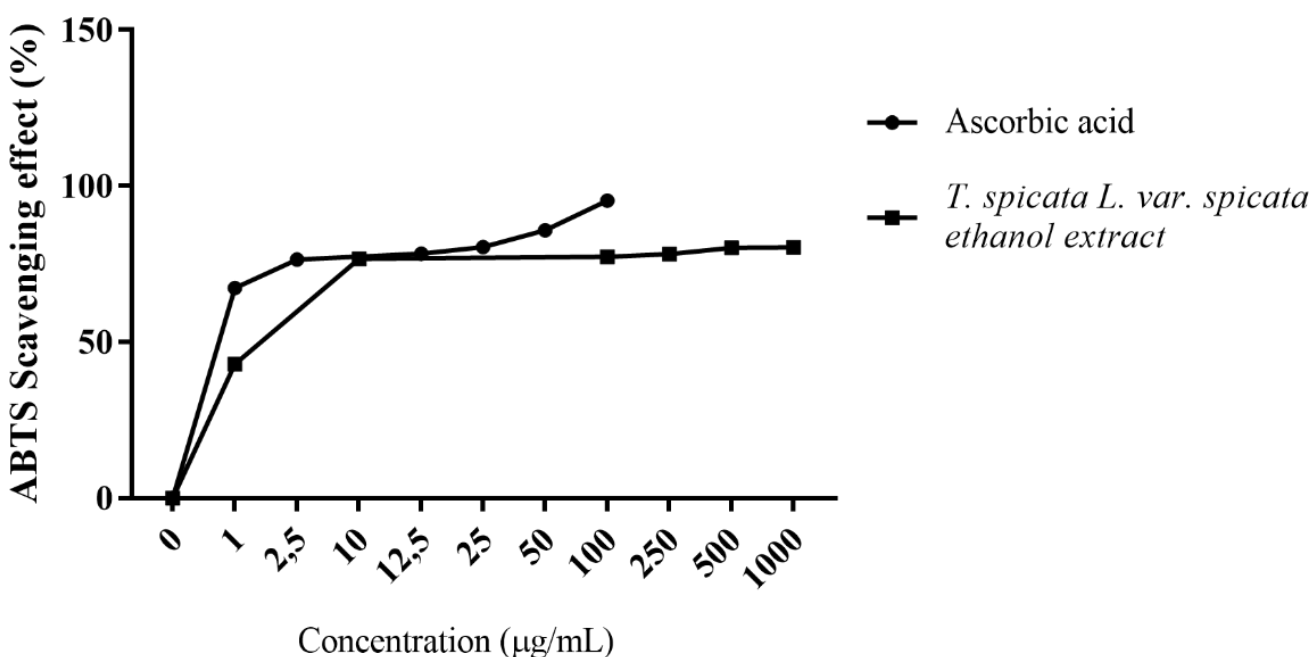

Figure 2. ABTS radical scavenging activity of ethanol extracts of T.spicata L.var. spicata

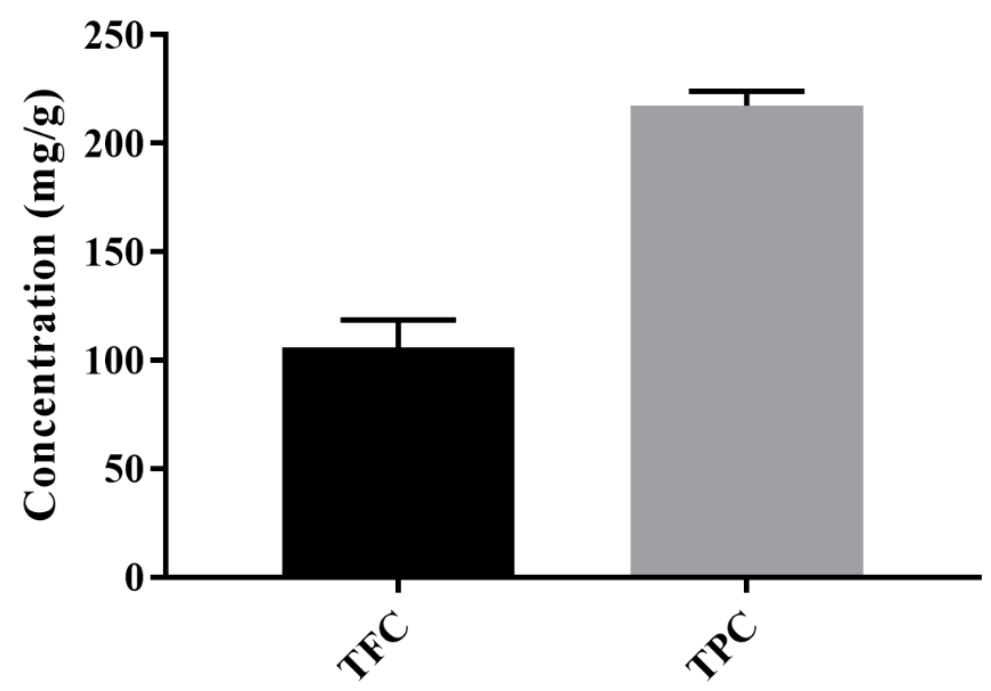

Figure 3. Total phenolic (TPC) and flavonoid (TFC) content of ethanol extracts of T.spicata L.var. spicata

The total phenolic and total flavonoid contents of ethanol extracts of T.spicata L.var. spicata revealed significant amounts of TPC and TFC as given in Figure 3. Total phenolic content in the extract $217.37 \mathrm{mg} / \mathrm{g}$ GAE and total flavonoid content was $105.97 \mathrm{mg}$ quercetin equivalent flavonoid in $\mathrm{g}$ dry weight of extracts. Though the bioactivity of flavonoids appears to be mediated through a variety of mechanisms, particular attention has been focused on their direct and indirect antioxidant actions.

\section{Antimicrobial activity}

MIC values of the ethanol extract of T.spicata L.var. spicata was detected with broth microdilution assay. As can be seen from the Table 1 , plant extracts showed different antimicrobial activity against the test microorganisms. MIC values of the extracts in the range between 1.25$2.5 \mathrm{mg} / \mathrm{mL}$. According to the results, E.faecalis was the less sensitive against the extract of T.spicata L.var. spicata then other microorganisms which have the lowest MIC values $2.5 \mathrm{mg} / \mathrm{mL}$. In previous studies, it was reported that the T.spicata 
extracts was potentiated the antimicrobial properties of antibiotics from 8 to 128 fold against multridrug resistant strains when combinated with T.spicata extract ${ }^{20}$. In current study, the MIC value for all the tested strains was lower than the reports as $6.25-100 \mathrm{mg} / \mathrm{mL}$ for ethanol, aqueous and petroleum ether extract, which reflects a good antibacterial effect against studied strains.

Table 1. Minimum inhibitory concentrations of ethanol extrat of T.spicata L. var. spicata

\begin{tabular}{lll}
\hline & Ethanol extract & $\mathrm{mg} / \mathrm{mL}$ \\
\hline S/No. & Microorganisms & \\
\hline 1 & E.coli & 1.25 \\
\hline 2 & S.aureus & 1.25 \\
\hline 3 & P.aeruginosa & 1.25 \\
\hline 4 & E.faecalis & 2.5 \\
\hline 5 & C.albicans & 1.25 \\
\hline
\end{tabular}

\section{Cytotoxicity assay}

The proliferative effect of plant extracts on cell growth was assessed by 3-(4,5-dimethylthiazol-2yl)-2,5-diphenyltetrazolium bromide (MTT) assay. This colorimetric assay is based on the conversion of the yellow tetrazolium bromide (MTT) to the purple formazan by the action of mitochondrial enzyme succinate dehydrogenase in viable cells. The results indicate that ethanol extract have antiproliferative activity aganist MCF-7 cancer cells with $\mathrm{IC}_{50}$ of $340 \mu \mathrm{g} / \mathrm{mL}$, while not effecient on PC-3 human prostate cancer cells (Figure 4). The hydro-alcoholic extract of T.spicata on lung cancer cell line SK-Mes-1 exhibited dosedependent cytotoxic effect and $\mathrm{IC}_{50}$ was determined as $110 \mu \mathrm{g} / \mathrm{mL}^{21}$. The antiproliferative activity attributed to the chemical composition of the extract or essential oil. It has been studied that thymol and carvacrol are the major constituents of the plant either in essential oil and extract ${ }^{22}$. The main compounds also have been investigated for their biological activities. Thymol and carvacrol were found to be more potent against MCF-7 cancer cell lines than other compounds presented in the essential oil of S.thymbra ${ }^{23}$. Carvacrol has been studied against various cancer cell lines and showed moderate to strong antiproliferative activity $^{24-27}$. When these data taking into consideration, it is possible that the amounts of the thymol and carvacrol in the extract or essential oil determine the degree of antiproliferative effect or other biological activities.

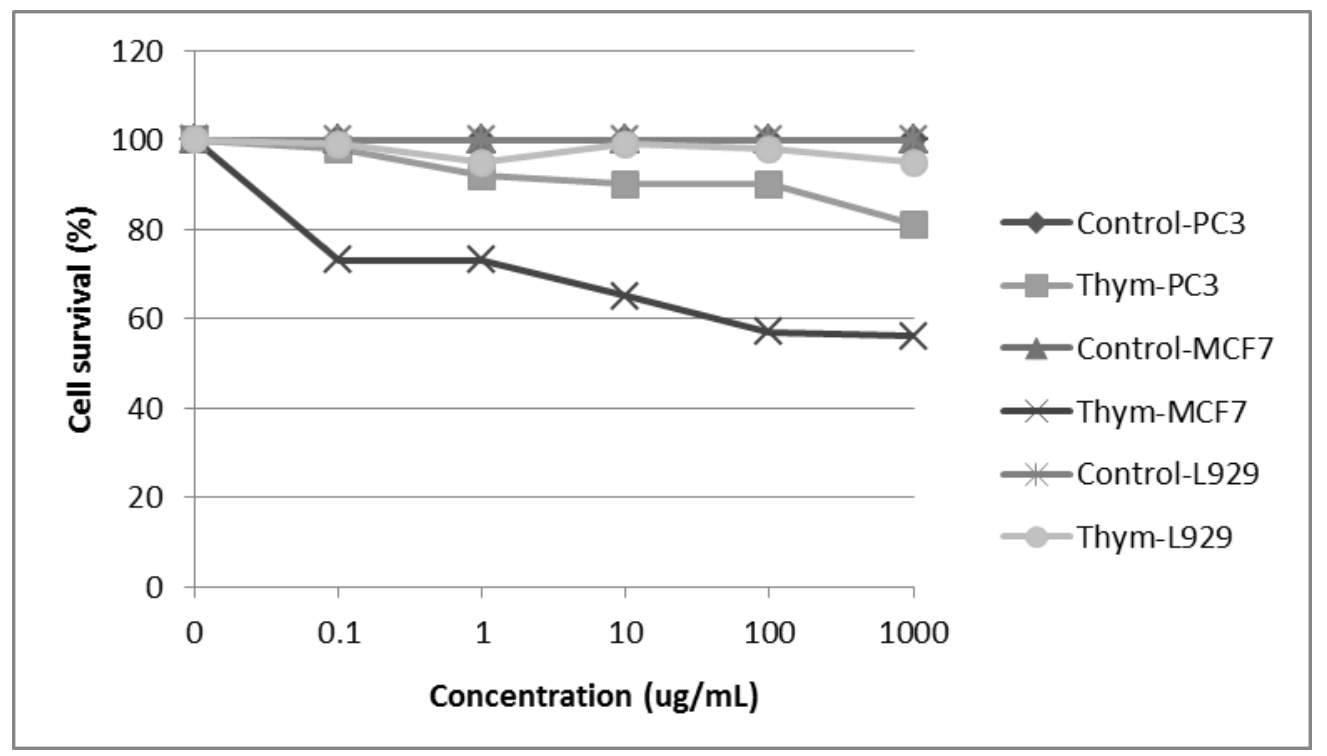

Figure 4. Cytotoxicity activity of ethanol extracts of T.spicata L.var. spicata 


\section{CONCLUSION}

In the light of our results of investigations, it can be conclude that the ethanol extract of T.spicata herein exhibited strong antioxidant, antimicrobial and antiproliferative potential, it may be related with the presence of higher content of phenolic and flavonoid compounds. These findings confirm the use of the studied plants in Turkish ethnomedicine. This is the first study as far as we are aware that the antiproliferative activity of the ethanol extract of T.spicata has been studied. The results of the present study show that the ethanol extract T.spicata contained a high total phenolics level, and can be a promising source of antioxidant, antibacterial as well as health-promoting agents; therefore, it can be considered potentially useful for medicinal application. However, more detailed in vivo studies are required to make firm the safety, bioavailability and quality control of T.spicata L.var. spicata as well as and further research linked to identify the active molecule via bioassay-guided isolation.

\section{Acknowledgement}

The authors would like to thank Dr. Mehmet Tekin from Department of pharmaceutical botany, Faculty of Pharmacy, Cumhuriyet University, Sivas- Turkey for identification of plant material.

\section{REFERENCES}

1. Zingue S, Job Tchoumtchoua DMN. Estrogenic and cytotoxic potentials of compounds isolated from Millettia macrophylla Benth (Fabaceae): towards a better understanding of its underlying mechanisms. BMC Complement Altern Med. 2016; 16: 1.

2. Lobo V, Patil A, Phatak NC. Free radicals, antioxidants and functional foods: Impact on human health. Pharmacogn Rev 2010; 4: 118-26.

3. Abdulla Al-Mamun M, Husna J, Khatun M, Hasan R, Kamruzzaman M. Assessment of antioxidant, anticancer and antimicrobial activity of two vegetable species of Amaranthus in Bangladesh. BMC Complement Altern Med 2016; 16: 157.

4. Halliwell BGJ. Cellular responses to oxidative stress: adaptation, damage, repair, senescence and death. In: Halliwell B GJ, ed. Free Radicals in Biology and Medicine. New York: Oxford University Press; 2007: 187-267.
5. Moniba Sajid, Muhammad Rashid Khan, Naseer Ali Shah, Sayed Afzal Shah, Hammad Ismai TY and ZZ. Phytochemical, antioxidant and hepatoprotective effects of Alnus nitida bark in carbon tetrachloride challenged Sprague Dawley rats. BMC Complement Altern Med 2016; 16: 268.

6. Aswathanarayan JB VR. In vitro evaluation of antioxidant and antibacterial activities of Rotula aquatica and Ancistrocladus heyneanus antioxidant and antimicrobial activity of medicinal plants. J Pharm Res 2013; 6: 313-7.

7. H DP. Flora of Turkey and The East Aegean Islands. Edinburgh: Edinburgh University Press; 1982.

8. Tanker, M., Ilisulu F. Thymbra spicata L. var. spicata: one of the plants used in Turkey as thyme. Turk J Bot 1984; 8: 1048.

9. Kizıl S. Determination of essential oil variations of Thymbra spicata $L$. var. spicata naturally growing in the wild flora of East Mediterranean and Southeastern Anatolia regions of Turkey. Ind Crops Prod 2010; 32: 593-600.

10. Dogan S, Turan P, Dogan M, Arslan O AM. Partial characterization of peroxidase from the leaves of Thymbra plant (Thymbra spicata L. var. spicata). Eur Food Res Technol 2007; 225: 865-71.

11. Blois M. Antioxidant determination by the use of a stable free radical. Nature 1958; 181: 1199-200.

12. Roberta Re, Nicoletta Pellegrini, Anna Proteggente, Ananth Pannala, Min Yang CR-E. Antioxidant activity applying an improved ABTS radical cation decolorization assay. Free Radic Biol Med 1999; 26(9-10): 1231-7.

13. Hana M. Hammad, Camelia Albu, Suzan A. Matar, Simona-Carmen Litescu, Hala I. Al Jaber, Amal S. Abualraghib FUA. Biological activities of the hydroalchoholic and aqueous extracts of Achillea biebersteinii Afan. (Asteraceae) grown in Jordan. African J Pharm Pharmacol 2013; 7: 1686-94.

14. Misbah H, Aziz AA AN. Antidiabetic and antioxidant properties of Ficus deltoidea fruit extract and fractions. BMC Complement Altern Med 2013; 13: 118. 
15. Eloff JN. A sensitive and quick microplate method to determine the minimal inhibitory concentration of plant extracts for bacteria. Planta Med 1998; 64: 711-3. doi:10.1055/s2006-957563.

16. Vittorazzi C, Endringer DC, Andrade TU De, Scherer R, Fronza M. Antioxidant, antimicrobial and wound healing properties of Struthanthus vulgaris. Pharm Biol 2015; 10:1-7. doi:10.3109/13880209.2015.1040515.

17. Yilmaz O, Akkaya H. Radical Scavenging Activity of Thymbra spicata and Quercus ithaburensis in a Fenton Reagent Environment and Their Protective Effects on Unsaturated Fatty Acids. 2012; 40: 3440. doi:10.5053/ekoloji.2012.854.

18. Ceylan R, Zengin G, Uysal S, et al. GC-MS analysis and in vitro antioxidant and enzyme inhibitory activities of essential oil from aerial parts of endemic Thymus spathulifolius Hausskn. et Velen. J Enzyme Inhib Med Chem 2016; 31: 983-90. doi:10.3109/14756366.2015.1077822.

19. Iauk L, Acquaviva R, Mastrojeni S, et al. Antibacterial, antioxidant and hypoglycaemic effects of Thymus capitatus (L.) Hoffmanns. et Link leaves' fractions. J Enzyme Inhib Med Chem 2015; 30: 360-5. doi:10.3109/14756366.2014.930453.

20. Haroun MF, Al-kayali RS. Synergistic effect of Thymbra spicata L . extracts with antibiotics against multidrug- resistant Staphylococcus aureus and Klebsiella pneumoniae strains. Iran J Basic Med Sci 2016; 19: 1193-200.

21. Sabz Ali S, Rostam Zad A, Panahi J, Havasian M, Kaghani K, Bakhtiary S. Investigation on the inhibitory effects of Hydro-alcoholic extract of Thymbra spicata on the growth of Lung Cancer Cell Line SK-Mes-1. J Ilam Univ Med Sci 2014; 22: 153-8.

22. Hanci, S., Sahin, S., Yilmaz L. Isolation of volatile oil from thyme (Thymbra spicata) by steam distillation. Nahrung 2003; 47 : 252-255.

23. Fitsiou E, Anestopoulos I, Chlichlia K, Galanis A, Biology M. Antioxidant and Antiproliferative Properties of the Essential Oils of Satureja thymbra and Satureja parnassica and their Major Constituents.
2016; 5764: 5757-63. doi:10.21873/anticanres.11159.

24. Yin QH, Yan FX, Zu XY, Wu YH, Wu XP, Liao MC, Deng SW, Yin LL, Zhuang YZ.QH Y, FX Y, XY Z. Anti-proliferative and pro-apoptotic effect of carvacrol on human hepatocellular carcinoma cell line HepG-2. Cytotechnology 2012; 64: 43-51.

25. Arunasree K. Anti-proliferative effects of carvacrol on a human metastatic breast cancer cell line, MDA-MB 231. Phytomedicine 2010; 17(8-9): 581-8.

26. Mehdi SJ, Ahmad A, Irshad MD, Rizvi M. Cytotoxic effect of Carvacrol on human cervical cancer cells. Biol Med 2011; 3: 307-12.

27. Sivas H TÖ. Antiproliferative and apoptotic effects of the essential oil of Origanum onites and carvacrol on Hep-G2 cells. Univ J Sci Technol C Life Sci Biotechnol. 2011; 7: 171-80. 